\title{
Political Economy of Indonesia Sustainable Palm Oil (ISPO) Certification System in Riau Province
}

\author{
Dedi Kusuma Habibie S.I.P MPA \\ Magister of Public Administration, Universitas Gadjah Mada \\ habibiemap@gmail.com
}

\begin{abstract}
The Indonesian oil palm industry has experienced many dynamics at both global and national levels; the prospect of oil palm business continues to improve every year, as well as the demand for palm oil products that tend to increase, plus various palm derivative products and even palm oil can be made alternative renewable energy that would later replace petroleum made from fossil. It certainly raises various motives of interest for palm oil business actors as well as businesses that are directly related to the oil palm plantation business. Author summarized various issues to explain the dynamics of Indonesian palm oil development since the introduction of ISPO certification and describe how political economy policy of ISPO certification in one of the provinces in Indonesia which has the largest plantation area namely Riau Province. Several topics discussed, First, ISPO certification for whom? (Explaining what, how and for whom), Secondly, the dynamics of the ISPO certification policy in Riau Province, and, Third, relations between ISPO Certification and Sustainable Development Practices in Riau Province.
\end{abstract}

Keywords: Political economy; ISPO certification; Sustainable development

\section{Introduction}

\section{The dynamics of Indonesian palm oil}

Indonesia's oil palm industry has experienced many dynamics at both global and national levels. On a global level, the European Parliament voted on January 17 to approve a proposal entitled "Proposal for the Directive of the European Parliament and the Council on the Promotion of the use of Energy from Renewable Sources" (Rahma, 2018). One of the proposed points is prohibiting the use of coconut oil palm oil for biodiesel starting in 2021 and the discourse applies a single certification for oil palm production entered in the EU (Simon, 2018).

The dumping ${ }^{1}$ issue which states that the domestic palm oil biodiesel price of the Republic of Indonesia is lower than the price of biodiesel parity, and the protection of several palm oil importing countries by increasing the import duty tariff (Sari, 2017), the issue that palm oil is not environmentally friendly product (Berita Satu, 2018).

Various issues to consider related to the development of the Indonesian palm oil industry First, the competition of vegetable oil business in the international market for raw materials of biodiesel products, and other derivative products for foodstuffs, materials for daily use (Telapak Indonesia, 2017). Second, the discussion of environmental issues (environmental degradation,

\footnotetext{
${ }^{1}$ Dumping is a trading practice perpetrated by an exporter by selling a commodity on the international market at a price less than a reasonable value or lower than the price of the item in his own country.
} 
global warming, arson, deforestation) and social issues (welfare, agrarian conflict, human rights violations, social disparities). Third, the development of various principles of palm oil plantation management such as sustainable, green palm, clean production, this is also the background of the emergence of various kinds of certification. Fourth, protection carried out by several palm oil importing countries as a form of nationalist state economic movement (Elisabeth, 2009,p. 25). Fifth, not only the certified palm oil producers, the future buyers of palm oil are also certified, the scorecard report released by WWF contains an overview of how palm oil buyers can support sustainability (WWF Report, 2013, p. 3).

Figure 1

A highly Efficient Crop and Growing Global Demand
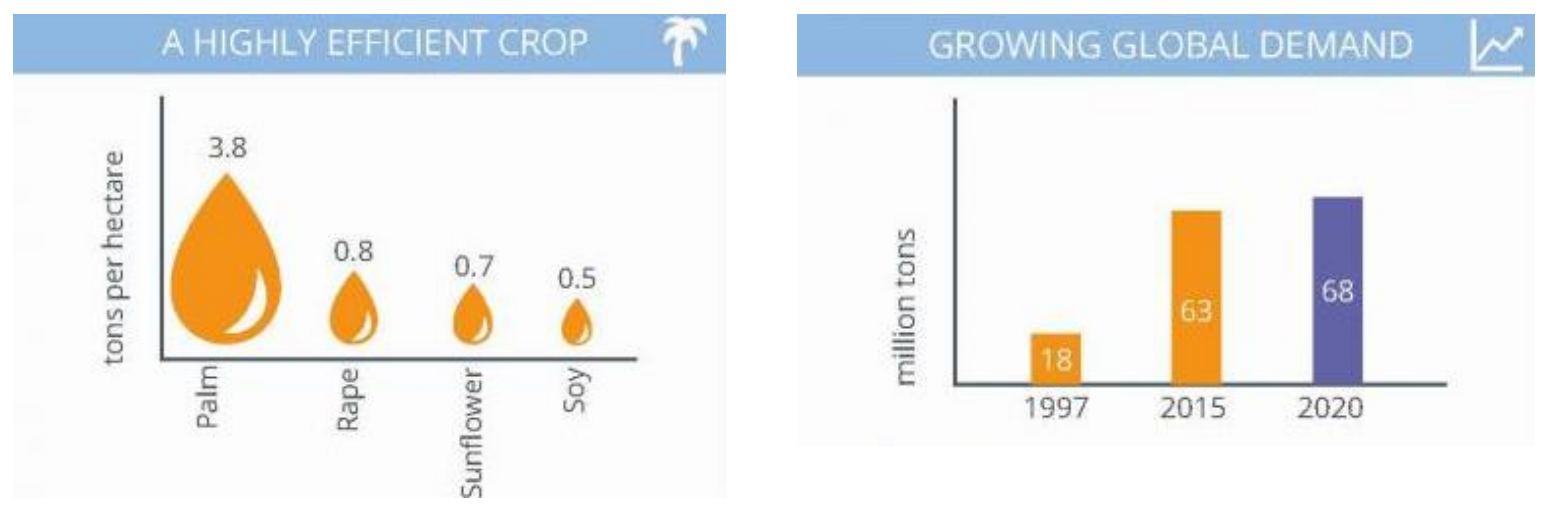

Source: European Palm Oil Alliance

For Indonesia, oil palm commodities have a very strategic value to support national development, 1) prime movers of agribusiness development from upstream to downstream 2) providers of substantial employment and as a source of farmer income, and 3) one of commodities that have a big role in generating foreign exchange state (Suharto et al, 2015,p. 5).

At the national level, the development of the palm oil industry is heavily influenced by various issues. First, the issue of land tenure rights between communities and companies (private) or communities with government (PTPN) tends to lead to various violations of human rights and cause injustice.

Second, the lack of awareness for palm oil plantation actors against the protection of the use of primary natural forests and peat lands, deforestation in concession and land conversion areas, burns land for the opening and preparation of new land for oil palm plantations. Third, the legality of plantation business, many plantation companies that do not have legality of plantation business especially location permit, plantation business license, plantation business status, right of land in the form of Right of Use (HGU) and corporate legal form. Fourth, the movement of antipalm oil has been empowered by some non-government organization (domestic and foreign NGO). 
Fifth, the national oil palm business still focuses on the upstream industry, since there are still much homework to be completed in the upstream industry, and insufficient $5 \mathrm{M}$ (Man, Money, Machine, Material and Managerial) as the supporting element of the downstream industry.

\section{Literature review}

In 2011 the Government of Indonesia established the guidelines for Indonesia's sustainable palm oil plantation or known as ISPO (Indonesian Sustainable Palm Oil), then in 2015 the Government through the Ministry of Agriculture stipulates Ministerial Regulation no. 11 of 2015 on Indonesia Sustainable Palm Oil Certification System, this is a government effort to respond and support sustainable development in the field of plantation especially in palm oil commodity.

ISPO certification policy is a form of government attention to the development of palm oil market in the world, various policies related to the certification of palm oil have been issued by various palm oil producing countries and palm oil consumer countries, Malaysia for example, with RSPO certification (Roundtable on Sustainable Palm Oil) is an international multi-stakeholder organization, adopting 3P-related MDGs in principles and criteria (P\&C), then MPOCC (Malaysian Palm Oil Certification Council), ISCC (International Sustainability \& Carbon Certification), Sustainable Agriculture Network (SAN) (Angus, 2017, p. 5) etc.

Generally, governance, who is involved, indicators used, assessment aspects etc. used for oil palm certification vary widely, but in general certification conducted by the state or a combination of international organizations aims to ensure that every business of oil palm (plantation, processing, sales) have an attention to the preservation of the environment. In detail there are reports published by EFECA (Economic Climate Environment) related to the comparison of ISPO, MSPO, and RSPO, in the report there is the biggest difference between RSPO and ISPO / MSPO is the inclusion of directives on business practices and plantation management (Economic Climate Environment,2017).

The existence of mutual agreement between UN member states SDGs (Sustainable Development Goals) in 2030, with the principle of development of "No One Will be Left Behind" is expected to give a positive influence on the implementation of ISPO policy. The existence of common objectives described in the ISPO principles and criteria can make it easy for related parties to actively contribute to the implementation of certification policies.

The principles and criteria of ISPO Sustainable Palm Oil Plantations: a) Licensing and Estate Management System, b) Implementation of Technical Guidelines for Cultivation and Processing of Oil Palm, c) Environmental Management and Monitoring, d) Responsibility of Workers, e) Social and Community Responsibility, f) Empowering Community Economic Activity, g) Continuous Business Improvement. Basically, ISPO guidelines are based on four things: legal compliance (Licensing, Business Legality etc.), business feasibility (business governance, business management etc.), environmental management (AMDAL, UKL, UPL etc.) social relations (Responsibility for workers, social, and community etc.).

The various principles and criteria of ISPO aims to regulate the management of the Indonesian oil palm plantation industry in order to produce environmentally friendly products and 
in the long run will increase Indonesia's palm oil competitiveness in the international vegetable oil market.

\section{Discussion}

\section{ISPO Certification for Whom?}

The presence of globalization will be in line with global competition. Global competition will encourage every country, and each country's business actors innovate sustainably in skills (Kuncoro: 2012), skills in packaging ISPO certification by taking into account the principle of sustainable development to be a positive value for the development of Indonesia's oil palm business.

Reviewing the ISPO certification system a) Business actors certified, obligatory for plantation business (UP) class I, II and III who conduct integrated plantation cultivation business, plantation cultivation and processing only. Voluntary to the plasma plantation, self-help and palm oil for renewable energy, b) the actors involved in the certification are 1) certification body (neutral third party), 2) the consultant agency, 3) the ISPO Commission and 3) the accreditation body, c ) ISPO as a certification has 7 principles, 40 criteria and 128 indicators.

ISPO certification is a policy that when viewed as a system, then policy has its constituent elements. According to Thomas R Dye (Dunn 2000: 110) there are three policy elements that make up the policy system. Dye describes all three elements of the policy as public policy, policy actors, and policy environment.

Figure 2

Three Policy Elements

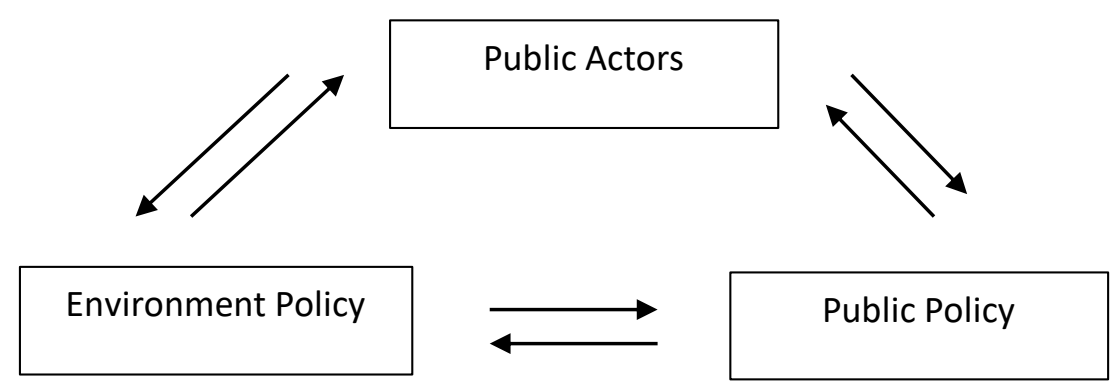

Source: Dunn 2000: 110

Public policy: ISPO certification is a policy adopted by the Indonesian government to improve the competitiveness of Indonesian palm oil in the world market, and the government's commitment to environmentally friendly palm oil production efforts by taking into account the principles of sustainable development in all palm oil business activities as well as comprehensive to the palm oil business actors (BUMN, Private, Community). 
Policy Actors: ISPO certification implemented by the Government in this case the Ministry of Agriculture through the ISPO Commission and the Directorate General of Plantation and also assisted by the Ministry of Home Affairs in this case the Local Government. The actor who plays an important role is the ISPO Commission because this institution is entitled to issue approval of the ISPO certification, while the Regional Government has the authority to impose sanctions on companies that do not participate in ISPO certification.

Environment Policy: the scope of the ISPO certification policy not only strives to achieve sustainable palm oil governance, but to provide answers to domestic and international demand for improvements in palm oil governance, it is therefore important to look at the level of level responses (demands / support) local, national and international as the policy environment response to the policy of certification.

\section{Dynamics of ISPO certification policy in Riau Province}

"Success of a policy if there is a relationship between the implementation of policies with the goals set" (Dunn 2000: 25). UN document "Integration of the three components of sustainable development - economic development, social development and environmental protection - as interdependent and mutually reinforcing pillars" (United Nations, 2002). There are five types of palm development outcomes that the government should pay attention to, and the palm oil industry actors: 1) Local economic benefits, community benefits, district palm governance, environmental impacts and carbon emissions from oil palm development ( Paoli, gary D, et al, 2011, p. 6)

Riau Province becomes area with widest palm oil plantation in Indonesia, data of DITJENBUN in 2014 of plantation area 2,290,736 ha with total production 6,993,241 tons. Ministry of Agriculture 346 ISPO certified companies or about $20.49 \%$ of the total Indonesian palm oil companies (Valid News,2017). By 2015, out of 187 oil palm companies in Riau, 22 of them have received ISPO certificates of $11.7 \%$.

The small number of ISPO certified companies is influenced by various factors. First, agrarian conflict, the 2016 Agrarian Renewal Consortium (Konsorsium Pembaruan Agraria, 2016) states that Riau is the province with the highest agrarian conflict in Indonesia is $9.78 \%$. Various efforts have been made both Litigation and Non-Litigation. The problem is the settlement of the conflict does not pay attention to the cause of the dispute. On the other hand, the law enforcement is still weak causing discrimination in the application of law resulting in justice in law has not materialized.

Second, the company's awareness of environmentally friendly plantation business is still low. Many companies do not meet the criteria of environmental management, forest and land fire cases in Riau (Fitria,2016), the number of burnt land from July $1^{\text {st }}$ to October $20^{\text {th }}, 2015$ reached 169,119 ha (Nugroho,2015, p. 3), impact on moratorium policy and tightening of various permits environmental management for business actors. Third, Integration of spatial map of agriculture sector especially palm oil spatial is not adequate, the need of spatial mapping in the form of map of forest area coming from Ministry of Environment and Forestry, map holder of Right of Use 
(HGU) in BPN office, Plantations issued by the local government (Ministry of Agrarian Affairs, 2016)

Fourth, ISPO certification is only in demand by companies with external market interests (export orientation), transparency and traceability of palm oil production is also weak, consequently the initiative for smallholder plantation as a supplier of fresh fruit bunch (FFB) for palm oil producing companies also fairly minimal. Fifth, the number of actors involved in the certification, causing a variety of interests so vulnerable to conflicts of interest, in addition the authority of the ISPO Commission is too large will interfere with other actors so that the process of check and balance in each stage of ISPO certification will be difficult to implement.

\section{Between ISPO certification and sustainable palm oil planting in Riau Province}

The management of natural resources in Indonesia has proven to be not only a process of economic interest - business only. Political battles are also present in the process of managing natural resources in Indonesia. (Hafid 2012: 26). As a large government organization with such complex activities requires funding to run various programs of government activity, the government has an interest in mobilizing and stimulating economic conducive activities.

According to Tomich et al (1995) the fast-growing agricultural sector will be able to increase the income and welfare of the rural population, which in turn can increase the demand for goods and services produced by the non-agricultural sector. Growing demand not only for products for final consumption, but also non-agricultural sector products was used by farmers as input for farming or for investment (Harianto 2009: 7).

Otsuka and readon 1998 (in Ian 2008: 11) The experience of Taiwan and Korea shows that a strong growth of agriculture and agro-industries can be an important tool for the development of non-agricultural activities, such as chemical, machinery, or metal industries. The Government recognizes that oil palm plantations will have a good impact on economic growth at the national level, as well as at the local level, Riau Province makes palm oil as a prima donna commodity that is widely cultivated by the public and business entities. There are several reasons

The author have an important record that ISPO certification and sustainable palm oil plantations in Riau Province work in tandem with complementarity First, maximizing existing land use by promoting increased productivity of oil palm, it is necessary to recall 38 thousand ha of palm oil in damaged Riau Province ( Directorate Geberal of Plantations, 2017)

Second, innovation or added value is much higher than the products of industry, by recognizing the products in the priority product (Kwik 1994: 3), it aims to develop the oil palm agro industry in both the upstream and downstream industries considering the product derivatives produced by palms are very varied (Telapak Indonesia, 2017)

Third, utilizing various materials of palm waste, all components of palm fruit can be utilized. They can be used as a compost, pulp and paper. The palm kernel shell can be used as fuel and carbon, while the core pulp can be used as animal feed. It will support the company that produces clean products (Clean Production). 
Fourth, maximizing human resources at the local level in the field of oil palm plantations, the high turnover of Human Resources in plantations due to lack of ready colleges and companies prepare a competent human resources superior and tough (Info Sawit, 2018), data percentage of population that has the highest diploma in Riau province shows the majority the population of Riau has the highest certificate in elementary school level 32,03\% while in Diploma level 2,28\% and Strata 1 and 2 and 3 equal to 5,69\% ( central Bureau of Statistics of Riau province, 2017).

Sutamihardja (Jaya 2004: 3), explains the various efforts that can be done for sustainable development: First, the equitable distribution of inter generation equity results meaning that the utilization of natural resources for the sake of growth should consider - reasonable limits in the control of the ecosystem or system and directed to a replaceable natural resource and emphasize the lowest possible exploitation of irreplaceable natural resources.

Second, safeguarding the sustainability of natural resources and the existing living environment and prevention of ecosystem disturbance in order to ensure the quality of life that remains good for the generations that come. Third, the utilization and management of natural resources solely for the purpose of pursuing economic growth for the benefit of equitable utilization of natural resources sustainably between generations.

Fourth, maintaining the welfare of the people (community) that is sustainable both present and future (inter temporal). Fifth, retain the benefits of development or management of natural resources and the environment that has the impact of long-term or sustainable generations. And sixth, maintaining the quality or quality of human life between generations in accordance with their habitat.

\section{Conclusion}

ISPO certification is the policy of the Indonesian government to improve the competitiveness of palm oil in the world market, the principles and criteria applied are the Indonesian government's efforts to realize sustainable palm oil plantation development, various dynamics continue to grow at both international and national levels, business competition among oil world vegetables, environmental issues, protection policies in international trade, the legality of community land and companies, the existence of anti-palm movement.

The government should have a strong commitment to maintain and develop efforts to build confidence in Indonesian oil palm plantations, various types of ISPO certification i.e. plantation company certification, plasma garden business certification, self-owned garden business certification, and certification of palm oil for renewable energy. Implemented effectively and efficiently by taking into account the three pillars of sustainable development (social, economic, environmental) and taking into account the various developments of the world's oil palm certification policies as input to ISPO certification recognized by the world market.

ISPO certification for whom, based on previous discussions, requires a harmonious understanding between the government, the private sector and the public in viewing the ISPO policy system (actors, policies and environment) holistically, the ISPO policy is not only related 
to economic motives but also as a government instrument to realize a palm oil business that cares about social values, and elements of the environment.

Riau Province is the province with the largest widest palm oil plantation and the largest palm oil producer nationally has many problems, to minimize the condition there are at least five types of palm development results that need to be considered by the government, and the palm oil industry actors: 1) Benefits 2) environmental impacts and 3) carbon emissions from oil palm development 4) environmental impacts and 5) carbon emissions from palm oil development (Paoli, gary D, et al, 2011, p. 19), as a note of the need to empower local industries linked to palm oil businesses, by buying or using products local for local oil palm business.

Between certification and sustainable palm oil plantation development in Riau Province is a debate that will continue to exist as long as the impacts or outcomes of oil palm plantations have not been felt significantly on the economic justice, social justice and environmental sustainability. Therefore, local governments, private companies and communities need to work together to address 1) efficient and efficient land use, 2) innovate palm oil business to develop oil palm agroindustry in upstream and downstream industries, 3) utilize all components of oil palm to support Clean Production, 4) maximize human resources at the local level in the field of oil palm plantations.

ISPO certification as one of the many plantation policies cannot work effectively if the central and local government awareness of environmental sustainability is low, therefore the principles of sustainable development can also be applied to political products. Green Politics Theory is a development effort that considers environmental sustainability in every policy formulation, green politics strongly supports the creation of just economy and sustainable development in Indonesia, awareness of environmental sustainability in the formulation of regional policy will accelerate the effort of development of sustainable palm oil plantation in Province Riau.

\section{References}

Bangun, Ian Persada. (2008). Perananan Sektor - Sektor Produksi Berbasis Pertanian Dalam Perekonomian Indonesia: Pendekatan Sistem Neraca Sosial Ekonomi (SNSE) Tahun 2008. unpublished Master of Economic Development UGM. Yogyakarta: Gadjah Mada University.

Berita Satu (2018, April 28). Resolusi sawit Eropa. beritasatu.com. Retrieved from http://id.beritasatu.com/home/resolusi-sawit-eropa/158903

Central Bureau of Statistics of Riau Province (2017). Riau in 2017 figures.bps.go.id. Retrieved from https://riau.bps.go.id/publication/2017/08/11/d2c73d2aa13099df12385547/provinsiriau-dalam-angka-2017.html

Directorate General of Palantations (2017). Tree crop estate statistics of Indonesia. ditjenbun.pertanian.go.id. Retrieved from http://ditjenbun.pertanian.go.id/tinymcpuk/gambar/file/statistik/2017/Kelapa-Sawit-20152017.pdf 
Dunn, William. (2000). Pengantar Analisis Kebijakan Publik Edisi Kedua (Terjemahan Samodra Wibawa, Diah Asitadani, Erwan Agus Purwanto). Yogyakarta: Gadjah Mada University Press.

Economic Climate Environment (2017). Comparison of the ISPO, MSPO and RSPO standards. Retrieved from https://www.sustainablepalmoil.org/wpcontent/uploads/sites/2/2015/09/Efeca_PO-Standards-Comparison.pdf

Elisabeth, Adriaana. (2009). Globalisasi dan perubahan politik Indonesia. Jurnal Ilmu Pemerintahan, 29

Fitria, Nurul. (2016, Desember 2). KLHK must enforce the law against 49 corporations. Jikalahari.or.id. Retrieved from http://jikalahari.or.id/kabar/rilis/klhk-harus-melakukanpenegakan-hukum-terhadap-49-korporasi/

Harianto. (2009). Peranan Pertanian dalam Ekonomi Pedesaan, Pusat Studi Pembangunan Pertanian dan Pedesaan. Bogor: Institut Pertanian Bogor.

Gie, Kwik Kian. (1994). Analisis Ekonomi Politik Indonesia. Jakarta: Gramedia Pustaka Utama.

Indonesian Republic's Agriculture Ministry the Malaysian Roundtable on sustainable palm oil (RSPO). (2015). Study Together Similarities and Differences Between The ISPO And RSPO Certification Systems. Jakarta.

Info Sawit (2018, March 2). 10 issues are discussed in the national palm oil gathering. Infosawit.com. Retrieved from https://www.infosawit.com/news/7773/10-isu-dibahasdalam-sarasehan-nasional-kelapa-sawit

Konsorsium pembaruan agraria (2016) Final report 2016. Agrarian liberalization is Increased, agrarian reform distracted. Retrieved from http://kpa.or.id/dummy/assets/uploads/files/publikasi/703f7-laporan-akhir-tahun-2016.pdf

Kuncoro, Mudrajad. (2012). Perencanaan Daerah, Bagaimana Membangun Ekonomi Lokal, Kawasan dan Kota. Jakarta: Salemba Empat.

Kurniawan, Wawan. Urgensi pembangunan agroindustri kelapa sawit berkelanjutan untuk mengurangi pemanasan global, universitas trisakti. Retrieved from http://taufiqurrachman.weblog.esaunggul.ac.id/wpcontent/uploads/sites/968/2016/06/TIN206-14-Jurnal-1-2015-2.pdf

Mclnnes, Angus. (2017). A comparison of leading palm oil certification standards. forestpeoples.org. Retrieved from https://www.forestpeoples.org/en/responsible-financepalm-oil-rspo/report/2017/comparison-leading-palm-oil-certification-standards

Ministry of Agrarian Affairs and Spatial Planning of the National Land Agency (2016). Spatial response to the challenges of the palm oil industry. bpn.go.id. Retrieved from http://www.bpn.go.id/BERITA/Siaran-Pers/tata-ruang-menjawab-tantangan-industrikelapa-sawit-65289

Nugroho, Sutopo P. (2015). Analysis of forest area and burning land in Indonesia 2015. National Board for Disaster Management. Retrieved from http://disasterchannel.co/wpcontent/uploads/2015/10/media_Analisis-luas-hutan-dan-lahan-terbakar-2015_30-Oktober2015.pdf 
Paoli,Gary D, et al. (2011). Nature report, oil palm in Indonesia: governance, decision making and the implications for sustainable development.The Nature Conservancy Indonesia Program. Retrieved from https://www.nature.or.id/publikasi/laporan.../sawit-di-indonesia.pdf

Raharjo, Hafid. (2012). Sengketa perebutan divestasi saham newmont Nusa Tenggara : Analisis ekonomi politik (2008-2012). Jurnal Ilmu Sosial dan Ilmu Politik , 16(1)

Rahma, Andita. (2018, February 2). Minyak kelapa sawit didiskriminasi Eropa, menlu retno kesal. Tempo.co. Retrieved from https://bisnis.tempo.co/read/1056541/minyak-kelapa-sawitdidiskriminasi-eropa-menlu-retno-kesal

Sari, Elisa Valenta. (2017, August 22). India jegal kelapa sawit Indonesia. CNN Indonesia.com. Retrieved from https://www.cnnindonesia.com/ekonomi/20170822153444-92236490/india-jegal-kelapa-sawit-indonesia

Simon, Frédéric (2018, January 10). EU heading for 'zero palm oil' in transport by 2021. euractiv.com. Retrieved from https://www.euractiv.com/section/energy/news/eu-headingfor-zero-palm-oil-in-transport-by-2021.

Suharto, Rosediana et al. (2015). Joint studies of similarities and differences of ISPO and RSPO certification systems [Kementerian Pertanian Republik Indonesia]. Retrieved from https://rspo.org/publications/download/255c19b8ae32d03

Telapak Indonesia (2017). Planting disaster: Menanam bencana. kaoemtelapak.org. Retrieved from http://www.kaoemtelapak.org/wp-content/uploads/2000/06/Planting_Disaster.pdf

United Nations. Retrived from United Nations. Retrieved from http://www.un.org/esa/sustdev/documents/WSSD_POI_PD/English/WSSD_PlanImpl.pdf

United Nations (2002). Plan of implementation of the world summit on sustainable development. Retrived from http://www.un.org/esa/sustdev/documents/WSSD_POI_PD/English/WSSD_PlanImpl.pdf

Valid News (2017. December 12). Almost 80 palm companies have not ISPO. validnews.co. Retrieved from http://validnews.co/Hampir-80--Perusahaan-Sawit-Belum-Kantongi-ISPOtoi

Widyaningsih, Dian \& Tri Wanalisis. (2017). Pangsa pasar dan daya saing CPO Indonesia di Uni Eropa, Gadjah Mada University. Retrieved from journals.ums.ac.id

WWF Report International. (2013). Palm oil buyers scorecard. WWF Report International 2013. Retrieved from http://www.wwf.se/source.php/1544243/Palm\%20Oil\%20Buyers\%20Scorecard\%202013.p df 